Original Article

\title{
Physiological responses of tambaqui (Colossoma macropomum) fed diets supplemented with silage from fish and vegetables residues
}

\author{
Respostas fisiológicas de tambaqui (Colossoma macropomum) alimentado com dietas \\ suplementadas com silagem de resíduos de pescado e vegetais
}

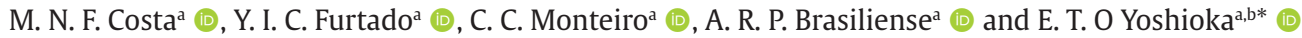 \\ aUniversidade Federal do Amapá - UNIFAP, Graduate Program in Tropical Biodiversity - PPGBIO, Macapá, AP, Brasil \\ ${ }^{\mathrm{b} E m p r e s a}$ Brasileira de Pesquisa Agropecuária - Embrapa, Aquaculture and Fisheries Laboratory, Macapá, AP, Brasil
}

\begin{abstract}
The demand for products to replace high-cost raw materials, such oil and fish meal, in the manufacture of feed for use in aquaculture, while also guaranteeing the nutritional quality of the diets, is increasing. Silage produced with fish and vegetables residues is a low-cost and efficient protein source. The objective of the present study was to evaluate the physiological and biochemical responses of tambaqui fingerlings fed four different levels of silage included in commercial feed with $28 \%$ crude protein, over two periods: 45 and 90 days. Each treatment was carried out over three replications, with 10 tambaqui in each 100 L experimental tank. At the end of each established period, blood samples were collected from five animals from each repetition to determine the hematological and biochemical variables. Body weight and total length, hepatosomatic and liposomal indices and hematocrit of specimens fed with diets supplemented with silage did not exhibit significant changes in both assessment period. After 45 days of feeding, the hemoglobin concentration increased when tambaqui were fed a diet including $20 \%$ silage. The red blood cell count, mean corpuscular volume and mean corpuscular hemoglobin did not change between treatments in either period. The total protein concentrations increased significantly in the plasma of tambaqui fed with diets with the inclusion of 5 and 10\% of silage, evaluated after feeding for 45 days. It was found that the groups which had silage included in their diet did not exhibit significant alterations in the evaluated parameters, and the diet was therefore not consider harmful to the health of tambaqui. Therefore, the use of silage as a feed supplement during tambaqui farming is a sustainable alternative for producers, as it leads to a reduction of impacts of fish and vegetables waste disposal.
\end{abstract}

Keywords: hematology, fish health, aquaculture, nutritional effects, fish farming.

\begin{abstract}
Resumo
A procura por insumos que substituam produtos de alto custo, como óleo e farinha de peixe, na fabricação de rações para uso na aquicultura é crescente, sendo necessário garantir a qualidade nutricional das dietas. A silagem produzida a partir de resíduos de pescado e de vegetais apresenta-se como uma alternativa de baixo custo e eficiente fonte proteica. $\mathrm{O}$ objetivo do presente estudo foi avaliar as respostas fisiológicas e bioquímicas de alevinos de tambaqui alimentados com quatro níveis de inclusão de silagem em ração comercial com $28 \%$ de proteína bruta, em dois períodos: 45 e 90 dias. Cada tratamento foi realizado em três repetições, com 10 tambaquis em cada caixa experimental de $100 \mathrm{~L}$. Ao término de cada período estabelecido, amostras sanguíneas foram coletadas de cinco animais de cada repetição para determinação das variáveis hematológicas e bioquímicas. Peso, comprimento total e índices hepatossomático e lipossomático de espécimes alimentados com silagem não mostraram alterações significativas em ambos os períodos de avaliação, bem como os valores de hematócrito. A concentração de hemoglobina de tambaqui após 45 dias de alimentação aumentou quando foi fornecida dieta com inclusão de $20 \%$ de silagem. A contagem de eritrócitos, volume corpuscular médio e hemoglobina corpuscular média não apresentaram alterações entre os tratamentos, em ambos os períodos. As proteínas totais aumentaram significativamente no plasma de tambaquis que receberam dietas com inclusão de 5 e $10 \%$ de silagem, avaliados após 45 dias de alimentação. Evidenciou-se que os grupos com inclusão de silagem na dieta não apresentaram alterações significativas nos parâmetros avaliados, assim não sendo prejudiciais à higidez do tambaqui. Portanto, o uso da silagem como suplemento alimentar durante o cultivo do tambaqui é uma alternativa sustentável para produtores, por promover a redução do descarte de resíduos de pescado e da agricultura.
\end{abstract}

Palavras-chave: hematologia, saúde animal, aquicultura, efeitos nutricionais, piscicultura.

*e-mail: eliane.yoshioka@embrapa.br

Received: August 18, 2021 - Accepted: January 2, 2022

This is an Open Access article distributed under the terms of the Creative Commons Attribution License, which permits unrestricted use, distribution, and reproduction in any medium, provided the original work is properly cited. 


\section{Introduction}

Tambaqui, Colossoma macropomum (Cuvier, 1818), belongs to the order Characiformes, and is considered the second largest scaly fish in the Amazon basin (Goulding and Carvalho, 1982). It has omnivorous feeding habits, with a preference for fruits and seeds (Araújo-Lima and Goulding, 1998). It is among the most important aquaculture species in the North of Brazil and is the third most cultivated fish in farms at a national level (Ruffino and Roubach, 2009). In the aquatic animal cultivation system, feed constitutes one of the largest final costs (Hisano et al., 2008), representing a significant expense to the producer, as the main products that make up the manufacture of feed, oil, and fish meal, are expensive. In view of this, many experimental studies have sought alternative products that can replace, or reduce, the use of these raw materials at a lower cost while ensuring the nutritional quality of the species under cultivation (Cyrino et al., 2010). Boscolo et al. (2004) showed that flour from tilapia (Oreochromis niloticus), corvina (Plagioscion squamosissimus) and shrimp (Macrobrachium amazonicum) residues can be used as ingredients in the formulation of fish feed, as a source of protein.

A suitable choice is the production of silage from fish processing residues, as well as agricultural residues (Paula and Faria Júnior, 2019; Guimarães et al., 2021), through a simple and low-cost method as biomass hydrolysis, come to high protein value product with rich in fatty acids and elevated biological value for animal nutrition (Rossetto and Signor, 2021). In addition to being an alternative and economically viable source for producers, it allows a reduction in the amount of waste disposed in the environment, such as that produced from underutilized species in fish farming and fisheries, rejects from the commercialization of fish and processing industries (Arruda et al., 2006; Cyrino et al., 2010; Oliveira et al., 2013; Guimarães et al., 2021; Rossetto and Signor, 2021).

The addition of pineapple peel in the elephant grass ensiling achieved positive results, mainly when the level of inclusion reached $50 \%$, with an increase in the crude protein content, close to $4.5 \%$, was observed by Bonfá et al. (2017). Yuangsoi et al. (2018) also used pineapple residues in the diet of fish, at a level of inclusion from 1 to $2 \%$, resulting in increased protein digestibility and fish growth, reduced ammonia level in water and, consequently, reduced nitrogen pollution. Therefore, it is observed that the production of silage with the remains of fruits, vegetables and fish residues can be alternative and economically viable sources for local producers with regard to fish nutrition, reducing the disposal of waste in the environment. However, considering the condition of confinement of animals in cultivation, in which they depend exclusively on the feed offered to them, one must ensure, among other factors, a diet that includes the greatest possible amount of nutrients (Chagas and Val, 2003; Rotta, 2003), since diet can modify the bodily functioning of the fish (Cyrino et al., 2010). Therefore, it is essential to achieve nutritional balance of fish farmed.

One way to monitor the health of these animals and understand how nutrition acts in the body is through hematological evaluations, which allow for information and diagnosis of the health status of specimens farmed (Ranzani-Paiva et al., 2013; Fazio, 2019). In this context, the objective of the present study was to verify the physiological responses of tambaqui (C. macropomum) after their diet was supplemented with silage produced with fish and vegetables residues.

\section{Material and Methods}

\subsection{Experimental diets and analyses}

This experiment is authorized by Ethics Committee for Animal Use of Embrapa Amapá (nr 015-CEUA/CPAFAP) and is registered in National System for the Management of Genetic Heritage and Associated Traditional Knowledge (SisGen) (nr A0D6DC0). The experiments were carried out at the Aquatic Organisms Nutrition Laboratory, Embrapa Amapá, from August 2019 onwards. The specimens of $C$. macropomum were purchased from a commercial fish farm from Macapá, state of Amapá. Tambaqui $(\mathrm{n}=120)$ with an initial average weight of $31.15 \pm 3.65 \mathrm{~g}$ were divided in groups of 10 in 12 circular water tanks ( $100 \mathrm{~L})$, acclimated to the laboratory conditions for 15 days, and fed with $28 \%$ crude protein feed (Acqualine, Supra, Alisul Alimentos S.A., São Leopoldo, Rio Grande do Sul, Brazil).

The silage produced with fish (a variety of fish species, as hake, Cynoscion leiarchus, yellow hake C. acoupa) and vegetables (as pineapple, avocado, and cabbage) residues were made in accordance with Yoshioka et al. (2020). A variety of fish and vegetables residues were mixed and fermented (with biological yeast, vinegar, and salt) for 10 days at room temperature and no light. The silage (Table 1) obtained was kept in a freezer until used in this study.

Silage was included in ground feed ( $28 \%$ CP feed) at four levels: $0 \%$ (Control, without silage), $5 \%$ (25 g of silage and $500 \mathrm{~g}$ of ground feed), 10\% (50 g of silage and $500 \mathrm{~g}$ of ground feed) and 20\% (100 g of silage and $500 \mathrm{~g}$ of ground feed), well mixed (water in an adequate quantity to join each doll and keeping a consistency to pass through a grinder) and passed through a meat grinder, dried in an oven $\left(50^{\circ} \mathrm{C}\right)$ for $24 \mathrm{~h}$ with forced air circulation, and broken into smaller pieces and kept in refrigerator until supplied to the fish. The distribution of diets in each experimental tank was carried out in a randomized way, in triplicate, to ensure maximum independence between the samples. The experimental diets produced for the feeding of the tambaqui were collected ( $100 \mathrm{~g}$ of each experimental diet), in triplicate, according to the guidelines of the Association of Official Analytical Chemists (AOAC, 1995) to analyze centesimal composition of the experimental diets. These diets were made up of dry matter, crude protein, ether extract and similar ashes and Table 1 shows the chemical composition of the experimental diets.

The feed daily amount was $5 \%$ of the biomass of each experimental box, divided into four parts and provided at 8:00 am, 11:00 am, 2:00 pm and 5:00 pm. The total feeding period was 90 days, with the following procedures performed after 45 and 90 days: collection of blood 
Table 1. Basal composition of commercial ration and proximate composition of silage and experimental diets supplemented with different percentages inclusions of silage from fisheries and vegetables by-products.

\begin{tabular}{cccccc}
\hline & Silage $^{\#}$ & \multicolumn{4}{c}{ Experimental diets } \\
\cline { 3 - 6 } & & $\mathbf{0 \%}$ & $\mathbf{5 \%}$ & $\mathbf{1 0 \%}$ & $\mathbf{2 0 \%}$ \\
\hline Dry matter (\%) & 25.09 & $94.14 \pm 0.14^{\mathrm{b}}$ & $94.37 \pm 0.15^{\mathrm{a}}$ & $94.09 \pm 0.09^{\mathrm{b}}$ & $94.05 \pm 0.07^{\mathrm{b}}$ \\
Crude protein (\%) & 10.37 & $24.19 \pm 1.86^{\mathrm{c}}$ & $28.23 \pm 0.38^{\mathrm{ab}}$ & $27.17 \pm 0.58^{\mathrm{b}}$ & $29.08 \pm 0.73^{\mathrm{a}}$ \\
Ether extract (\%) & 3.69 & $6.23 \pm 0.14^{\mathrm{d}}$ & $6.50 \pm 0.22^{\mathrm{c}}$ & $6.89 \pm 0.16^{\mathrm{b}}$ & $7.18 \pm 0.13^{\mathrm{a}}$ \\
Ashes (\%) & 3.02 & $14.01 \pm 0.31^{\mathrm{b}}$ & $15.13 \pm 0.38^{\mathrm{a}}$ & $15.05 \pm 0.25^{\mathrm{a}}$ & $14.86 \pm 0.21^{\mathrm{a}}$ \\
Phosphorous (\%) & 0.39 & $1.79 \pm 0.06^{\mathrm{c}}$ & $1.94 \pm 0.05^{\mathrm{b}}$ & $1.95 \pm 0.09^{\mathrm{b}}$ & $2.28 \pm 0.12^{\mathrm{a}}$ \\
Calcium (\%) & 0.28 & $3.50 \pm 0.47^{\mathrm{a}}$ & $3.63 \pm 0.05^{\mathrm{a}}$ & $3.21 \pm 0.39^{\mathrm{a}}$ & $2.00 \pm 0.38^{\mathrm{b}}$ \\
\hline
\end{tabular}

Data expressed as mean values \pm standard deviation. \#Yoshioka et al. (2020). Different letters mean significant differences by ANOVA, analysis followed by post-hoc Tukey $(\mathrm{P}<0.05)$.

samples from the specimens ( 15 from each treatment, five specimens from each repetition) to assess health status. After blood collection, the specimens were euthanized by spinal transection to obtain the total weight and total length; removal and weighing of the liver and visceral fat (lipid), to check the hepatosomatic (HSI=liver weight/ body weight $\mathrm{x}$ 100) and liposomatic (LSI= lipid weight/ body weight $\mathrm{x}$ 100) indices, respectively.

The blood samples were collected by caudal vessel puncture, using needles and syringes containing $\mathrm{Na}_{2}$ EDTA $3 \%$. Each blood sample was used to determine the hematocrit (Ht), hemoglobin concentration ( $\mathrm{Hb})$, and red blood cell count (RBC). These data were used to determine mean corpuscular volume (MCV), mean corpuscular hemoglobin $(\mathrm{MCH})$ and mean corpuscular hemoglobin concentration (MCHC) (Ranzani-Paiva et al., 2013). The remaining blood samples were centrifuged at $75 \mathrm{G}$ for 5 minutes (Centrifuge 5424, Eppendorf, Hamburg, Germany) to obtain the plasma, in order to determine the levels of glucose $\left(\mathrm{mg} \cdot \mathrm{dL}^{-1}\right)$, total protein $\left(\mathrm{g} \cdot \mathrm{dL}^{-1}\right)$, albumin $\left(\mathrm{g} \cdot \mathrm{dL}^{-1}\right)$, total cholesterol $\left(\mathrm{mg}^{\mathrm{d}} \mathrm{dL}^{-1}\right)$, and triglyceride $\left(\mathrm{mg} \cdot \mathrm{dL}^{-1}\right)$, using specific colorimetric kits (Ebram Laboratorial Products, São Paulo, SP, Brazil) for each metabolite, with absorbance readings from a spectrophotometer (Biospectro SP-220, Curitiba, Paraná, Brazil).

\subsection{Statistical analysis}

The data were firstly subjected to normality and homoscedasticity tests using the Shapiro-Wilk and Levene methods, respectively, and, where analyzed using ANOVA and post hoc Tukey and Kruskal-Wallis tests. Differences were considered significant at $5 \%$ probability (Zar, 2010). Data are presented as mean and standard deviation. The tests were performed using Graph Pad Instat (version 3.0, 1997) software.

\section{Results}

The inclusion of silage in the feed increased the amount of crude protein and lipids in the experimental diets (Table 1 ). In addition, diets with silage showed ashes quantities increased and reflected on higher levels of phosphorus and calcium observed. Although only the diet with inclusion of $20 \%$ silage showed lower amounts of calcium.

Diets supplemented with the inclusion of 5, 10 and $20 \%$ of silage were well accepted by the tambaqui during the provision of feed in the 90-day period of feeding trial. Mortalities were not verified all over the experimental period. However, the body weight, total length and HSI of the specimens did not change $(P>0.05)$ between the different experimental diets in the same period. In contrast, when comparing the 45- and 90-day feeding periods, a significant increase in the weight and length of the fish was found regardless of the level of inclusion of silage in the diets. HSI showed a decline in the group fed a diet supplemented with $20 \%$ silage for 90 days, in comparison with 45 days. After 45 days, a lower LSI was observed in tambaqui that received 5\% Silage than in the Control and $10 \%$ Silage groups. When fish were fed for 90 days, there were no differences $(\mathrm{P}>0.05)$ between the groups. However, there was a significant increase in LSI values when fed for 90 days, compared to 45 days (Table 2 ).

The Ht values of the tambaqui did not differ $(\mathrm{P}>0.05)$ due to silage supplementation, after either 45 or 90 days. However, Ht decreased significantly in the $5 \%$ silage and $20 \%$ silage groups fed for 90 days, when compared to those fed for only 45 days. In specimens that received the diet with the inclusion of $20 \%$ silage for 45 days, an $\mathrm{Hb}$ concentration increase $(\mathrm{P}<0.05)$ was observed, when compared with the Control group (Silage 0\%). However, a significant reduction in $\mathrm{Hb}$ in groups also fed diets with the inclusion of 5 and $20 \%$ silage was observed after 90 days of feeding, in comparison with the 45-day period (Table 3 ).

$\mathrm{RBC}, \mathrm{MCV}$ and $\mathrm{MCH}$ showed no changes between treatments at either period analyzed. However, significant differences after 90 days of feeding were observed. RBC declined significantly in the groups fed with 0, 5 and $10 \%$ silage for 90 days, compared to the respective groups after 45 days (Table 3 ). In contrast, the $\mathrm{MCH}$ values of the same groups increased significantly after 90 days of feeding. In addition, there was an increase in MCV in the group of tambaqui that received a $10 \%$ silage diet for 90 days, compared to those who were fed for 45 days. At 90 days, $\mathrm{MCHC}$ increased significantly in the Control group, being 
higher than that of the Control group after 45 days fed a diet supplemented with silage.

Table 4 presented glycemia levels increased $(P<0.05)$ in animals that received a $5 \%$ Silage diet for 45 days. In addition, total protein plasma levels increased significantly with 5 and $10 \%$ silage diets, in comparison with the other diets. However, the total protein levels of specimens receiving diets with 5 and $10 \%$ silage declined $(\mathrm{P}<0.05)$ when fed for 90 days, although when $20 \%$ silage was included, there was a significant increase in comparison with feeding for 45 days. After 90 days of feeding, albumin levels decreased when the tambaqui received a 5\% silage diet, compared to those that received diets with 10 and 20\% silage in their diets, and in comparison, with the 45-day period. In contrast, the $20 \%$ silage diet supplied for 90 days led to an albumin increase $(\mathrm{P}<0.05)$ in relation to the Control and $5 \%$ silage diet, and when comparing with those fish fed for 45 days (Table 4). Total cholesterol levels in the

Table 2. Body weight and total length, hepatosomatic (HSI) and liposomatic indices (LSI) (mean \pm standard deviation, $\mathrm{n}=15$ ) of Colossoma macropomum fed diets supplemented with fisheries and vegetables by-products silage (Silage 0\%, 5\%, 10\% e 20\%) for 45 and 90 days.

\begin{tabular}{|c|c|c|c|c|}
\hline & \multicolumn{4}{|c|}{ 45-Day period } \\
\hline & Silage $0 \%$ & Silage $5 \%$ & Silage $10 \%$ & Silage $20 \%$ \\
\hline Weight (g) & $60.40 \pm 11.27^{\mathrm{a}}$ & $61.20 \pm 12.90^{\mathrm{a}}$ & $57.47 \pm 10.72^{\mathrm{a}}$ & $67.73 \pm 12.39^{a}$ \\
\hline Total length (cm) & $15.33 \pm 1.19^{a}$ & $15.37 \pm 1.08^{\mathrm{a}}$ & $15.37 \pm 0.69^{a}$ & $16.10 \pm 0.94^{\mathrm{a}}$ \\
\hline HSI (\%) & $1.43 \pm 0.25^{\mathrm{a}}$ & $1.42 \pm 0.21^{\mathrm{a}}$ & $1.59 \pm 0.23^{\mathrm{a}}$ & $1.47 \pm 0.17^{a}$ \\
\hline \multirow[t]{3}{*}{ LSI (\%) } & $0.92 \pm 0.26^{\mathrm{a}}$ & $0.58 \pm 0.13^{b}$ & $0.91 \pm 0.27^{a}$ & $0.81 \pm 0.22^{\mathrm{ab}}$ \\
\hline & \multicolumn{4}{|c|}{ 90-Day period } \\
\hline & Silage $0 \%$ & Silage $5 \%$ & Silage $10 \%$ & Silage $20 \%$ \\
\hline Weight (g) & $117.47 \pm 23.83^{\mathrm{a} *}$ & $126.93 \pm 15.86^{\mathrm{a} *}$ & $119.27 \pm 20.86^{\mathrm{a} *}$ & $123.33 \pm 23.68^{\mathrm{a} *}$ \\
\hline Total length (cm) & $19.33 \pm 1.39^{a *}$ & $19.91 \pm 0.76^{\mathrm{a} *}$ & $19.41 \pm 0.95^{\mathbf{a}^{*}}$ & $19.44 \pm 1.23^{3^{a} *}$ \\
\hline HSI (\%) & $1.41 \pm 0.36^{\mathrm{a}}$ & $1.28 \pm 0.13^{\mathrm{a}}$ & $1.38 \pm 0.16^{\mathrm{a}}$ & $1.29 \pm 0.23^{2^{*}}$ \\
\hline LSI (\%) & $1.37 \pm 0.30^{\mathrm{a} *}$ & $1.13 \pm 0.33^{\mathrm{a}^{*}}$ & $1.50 \pm 0.24^{\mathrm{a}^{*}}$ & $1.18 \pm 0.31^{\mathrm{a}^{*}}$ \\
\hline
\end{tabular}

Data expressed as mean values \pm standard deviation. Different letters mean significant differences by ANOVA, analysis followed by post-hoc Tukey $(\mathrm{P}<0.05)$; asterisk $\left({ }^{*}\right)$ means significant difference $(\mathrm{P}<0.05)$ when comparing groups from 45 and 90 -day periods, from the same treatment, for the same parameter.

Table 3. Hematological variables and hematimetric indices (mean \pm standard deviation, $\mathrm{n}=15$ ) of tambaqui Colossoma macropomum fed diets supplemented with fisheries and vegetables by-products silage (Silage 0\%, 5\%, 10\% e 20\%) for 45 and 90 days.

\begin{tabular}{|c|c|c|c|c|}
\hline & \multicolumn{4}{|c|}{ 45-day period } \\
\hline & Silage $0 \%$ & Silage $5 \%$ & Silage $10 \%$ & Silage $20 \%$ \\
\hline Ht (\%) & $27.65 \pm 5.51^{\mathrm{a}}$ & $30.53 \pm 3.72^{\mathrm{a}}$ & $30.77 \pm 4.98^{\mathrm{a}}$ & $30.30 \pm 2.30^{\mathrm{a}}$ \\
\hline $\mathrm{Hb}\left(\mathrm{g} \cdot \mathrm{dL}^{-1}\right)$ & $7.39 \pm 1.29^{b}$ & $8.34 \pm 1.06^{\mathrm{ab}}$ & $7.92 \pm 0.98^{\mathrm{ab}}$ & $8.67 \pm 0.68^{\mathrm{a}}$ \\
\hline $\mathrm{RBC}\left(\mathrm{x} 10^{6} \mu \mathrm{L}^{-1}\right)$ & $2.15 \pm 0.41^{\mathrm{a}}$ & $2.15 \pm 0.62^{\mathrm{a}}$ & $2.05 \pm 0.57^{\mathrm{a}}$ & $1.78 \pm 0.51^{\mathrm{a}}$ \\
\hline $\mathrm{MCV}(\mathrm{fL})$ & $160.04 \pm 43.80^{\mathrm{a}}$ & $147.77 \pm 43.06^{a}$ & $159.25 \pm 40.35^{a}$ & $179.93 \pm 60.89^{a}$ \\
\hline $\mathrm{MCH}\left(\mathrm{g} \cdot \mathrm{dL}^{-1}\right)$ & $41.85 \pm 9.20^{\mathrm{a}}$ & $41.37 \pm 7.94^{\mathrm{a}}$ & $41.22 \pm 8.51^{\mathrm{a}}$ & $50.77 \pm 10.55^{\mathrm{a}}$ \\
\hline \multirow[t]{3}{*}{ MCHC (g.dL-1) } & $27.74 \pm 6.32^{\mathrm{a}}$ & $27.49 \pm 3.45^{\mathrm{a}}$ & $26.10 \pm 3.77^{a}$ & $28.67 \pm 2.34^{\mathrm{a}}$ \\
\hline & \multicolumn{4}{|c|}{ 90-day period } \\
\hline & Silage $0 \%$ & Silage $5 \%$ & Silage $10 \%$ & Silage $20 \%$ \\
\hline Ht (\%) & $25.37 \pm 3.29^{\mathrm{a}}$ & $26.96 \pm 3.29^{\mathrm{a} *}$ & $27.96 \pm 4.19^{\mathrm{a}}$ & $26.54 \pm 1.59^{\mathrm{a}^{*}}$ \\
\hline $\mathrm{Hb}\left(\mathrm{g} \cdot \mathrm{dL}^{-1}\right)$ & $8.61 \pm 0.68^{\mathrm{a}^{*}}$ & $7.58 \pm 0.83^{\mathrm{b} *}$ & $7.64 \pm 1.01^{b}$ & $7.88 \pm 0.73^{a b *}$ \\
\hline $\mathrm{RBC}\left(\mathrm{x} 10^{6} \mu \mathrm{L}^{-1}\right)$ & $1.52 \pm 0.43^{\mathrm{a}^{*}}$ & $1.50 \pm 0.32^{\mathrm{a}^{*}}$ & $1.47 \pm 0.35^{\mathrm{a}^{*}}$ & $1.46 \pm 0.47^{a}$ \\
\hline $\operatorname{MCV}(\mathrm{fL})$ & $181.94 \pm 58.59^{a}$ & $189.52 \pm 69.69^{a}$ & $203.48 \pm 51.16^{\mathrm{a} *}$ & $200.06 \pm 62.11^{a}$ \\
\hline $\mathrm{MCH}\left(\mathrm{g} \cdot \mathrm{dL}^{-1}\right)$ & $61.18 \pm 13.43^{\mathrm{a} *}$ & $54.52 \pm 11.77^{\mathrm{a}^{*}}$ & $55.17 \pm 11.79^{a^{*}}$ & $56.51 \pm 6.55^{\mathrm{a}}$ \\
\hline $\mathrm{MCHC}\left(\mathrm{g} \cdot \mathrm{dL}^{-1}\right)$ & $33.61 \pm 3.32^{\mathrm{a}^{*}}$ & $28.97 \pm 3.15^{\mathrm{b}}$ & $27.76 \pm 3.48^{\mathrm{b}}$ & $29.82 \pm 2.19^{b}$ \\
\hline
\end{tabular}

Ht: Hematocrit; Hb: Hemoglobin concentration; RBC: red blood cell count; MCV: mean corpuscular volume; MCH: mean corpuscular hemoglobin; MCHC: mean corpuscular hemoglobin concentration. Data expressed as mean values \pm standard deviation. Different letters mean significant differences by ANOVA, analysis followed by post-hoc Tukey $(\mathrm{P}<0.05)$; asterisk $\left(^{*}\right)$ means significant difference $(\mathrm{P}<0.05)$ when comparing groups from 45 and 90 -day periods, from the same treatment, for the same parameter. 
Table 4. Plasma metabolite profile (mean \pm standard deviation, $\mathrm{n}=15$ ) of tambaqui Colossoma macropomum fed diets supplemented with fisheries and vegetables by-products silage (Silage $0 \%, 5 \%, 10 \%$ e $20 \%$ ) for 45 and 90 days.

\begin{tabular}{|c|c|c|c|c|}
\hline & \multicolumn{4}{|c|}{ 45-day period } \\
\hline & Silage $0 \%$ & Silage $5 \%$ & Silage $10 \%$ & Silage $20 \%$ \\
\hline Glucose (mg.dL $\left.{ }^{-1}\right)$ & $53.94 \pm 8.13^{b}$ & $63.51 \pm 6.20^{\mathrm{a}}$ & $54.15 \pm 8.89^{b}$ & $50.38 \pm 8.85^{\mathrm{b}}$ \\
\hline Total protein (g. $\left.\mathrm{dL}^{-1}\right)$ & $3.25 \pm 0.46^{\mathrm{b}}$ & $3.82 \pm 0.28^{\mathrm{a}}$ & $4.53 \pm 0.61^{\mathrm{a}}$ & $3.25 \pm 0.35^{b}$ \\
\hline Albumin $\left(\mathrm{g} \cdot \mathrm{dL}^{-1}\right)$ & $0.94 \pm 0.19^{a}$ & $0.99 \pm 0.06^{\mathrm{a}}$ & $0.96 \pm 0.14^{\mathrm{a}}$ & $0.91 \pm 0.05^{\mathrm{a}}$ \\
\hline Total cholesterol $\left(\mathrm{mg} \cdot \mathrm{dL}^{-1}\right)$ & $94.49 \pm 14.12^{\mathrm{b}}$ & $101.37 \pm 9.15^{\mathrm{ab}}$ & $105.82 \pm 9.99^{\mathrm{a}}$ & $123.53 \pm 10.33^{\mathrm{a}}$ \\
\hline \multirow[t]{3}{*}{ Triglyceride $\left(\mathrm{mg} \cdot \mathrm{dL}^{-1}\right)$} & $143.54 \pm 26.95^{\mathrm{ab}}$ & $161.04 \pm 25.61^{\mathrm{a}}$ & $158.75 \pm 23.51^{\mathrm{a}}$ & $127.80 \pm 18.05^{\mathrm{b}}$ \\
\hline & \multicolumn{4}{|c|}{ 90-day period } \\
\hline & Silage $0 \%$ & Silage $5 \%$ & Silage $10 \%$ & Silage 20\% \\
\hline Glucose (mg.dL $\left.{ }^{-1}\right)$ & $59.20 \pm 13.11^{\mathrm{a}}$ & $56.91 \pm 10.89^{\mathrm{a}}$ & $51.97 \pm 6.93^{\mathrm{a}}$ & $56.42 \pm 11.61^{\mathrm{a}}$ \\
\hline Total protein (g. $\left.\mathrm{dL}^{-1}\right)$ & $3.71 \pm 0.37^{\mathrm{ab} *}$ & $3.25 \pm 0.76^{\mathrm{b} *}$ & $3.78 \pm 0.99^{\mathrm{a} *}$ & $3.77 \pm 0.55^{\mathrm{ab} *}$ \\
\hline Albumin $\left(\mathrm{g} \cdot \mathrm{dL}^{-1}\right)$ & $0.93 \pm 0.10^{\mathrm{bc}}$ & $0.91 \pm 0.12^{\mathrm{b} *}$ & $1.02 \pm 0.06^{\mathrm{ac}}$ & $1.04 \pm 0.08^{\mathrm{a}^{*}}$ \\
\hline Total cholesterol (mg.dL $\mathrm{mL}^{-1}$ ) & $123.53 \pm 10.33^{\mathrm{a} *}$ & $114.46 \pm 10.29^{\mathrm{a} *}$ & $113.94 \pm 7.89^{\mathrm{a} *}$ & $118.91 \pm 17.55^{\mathrm{a} *}$ \\
\hline Triglyceride (mg.dL $\left.{ }^{-1}\right)$ & $162.84 \pm 14.19^{\mathrm{a} *}$ & $152.25 \pm 16.27^{\mathrm{a}}$ & $165.27 \pm 12.03^{\mathrm{a}}$ & $153.19 \pm 25.05^{\mathrm{a} *}$ \\
\hline
\end{tabular}

Data expressed as mean values \pm standard deviation. Different letters mean significant differences by ANOVA, analysis followed by post-hoc Tukey $(\mathrm{P}<0.05)$; asterisk $\left({ }^{*}\right)$ means significative difference $(\mathrm{P}<0.05)$ when comparing groups from 45 and 90 -day periods, from the same treatment, for the same parameter.

plasma of the tambaqui increased significantly in the groups that received the 10 and $20 \%$ silage diets for 45 days. However, after 90 days of feeding, these levels remained similar between the experimental groups. All the total cholesterol levels were higher $(\mathrm{P}<0.05)$ at 90 days than at 45 days. Plasma triglycerides increased significantly following the use of silage 5 and 10\% diets for 45 days. They also increased $(\mathrm{P}<0.05)$ between 45 and 90 days of feeding with the 0 and $20 \%$ silage diets.

\section{Discussion}

The tambaqui fed diets containing silage produced with fish and vegetables residues, at the levels of supplementation evaluated, accepted the feed since fish grown, indicating that the inclusion of the supplement, until $20 \%$, did not negatively influence the diets consumption by the fish (Meurer et al., 2008). Such acceptance may be linked to the fact that fruits and seeds are already part of the diet of several species of native omnivorous fish, including tambaqui (Araújo-Lima and Goulding, 1998).

The silage supplementation led to an increase in the amount of crude protein and lipids in the diets related to diet without silage, even with enzymatic hydrolysis process that increase polypeptides and amino acids (Gao et al., 2021). Despite the fish growth observed, varying the inclusion levels of silage in diets did not result in significant benefits in their biometric parameters. Aride et al. (2021) did not report biometric significant tambaqui growth after fed diets with until 30\% inclusion of wild rice, Oryza spp. However, Vendruscolo et al. (2009) included biologically treated apple pomace in the diet of tilapia fingerlings and observed an increase in biometric parameters in comparison with the Control group.

No HSI change was observed between the treatments in either of the evaluated periods, indicating that the health conditions of the tambaqui from the experimental groups were similar, in addition to the fact that the inclusion of silage in the diets did not cause any harm to the animals. Corrêa et al. (2020) observed similar behavior in pacu (Piaractus mesopotamicus) and in hybrid tambacu, fed a diet containing biological fish silage. In addition, Lima and Ludke (2011) found that the inclusion of different levels of mango meal bran in the diet of Nile tilapia ( $O$. niloticus) did not modify HSI, reinforcing the viability of using silage produced with fish and vegetables residues in a fish farm. The LSI value of tambaqui fed a diet with $5 \%$ silage inclusion for 45 days was lower and indicates that these animals did not accumulate perivisceral fat, possibly due to a greater energy use (Boaventura et al., 2021). Moreover, feeding for 90 days the LSI of the tambaqui increase significantly, indicating that the animals adapted to the feeding management conditions.

The addition of silage to the diet of the tambaqui did not change the Ht values. Different proportions of camu-camu (Myrciaria dubia) in the diet did not cause significant changes to the hematological parameters of tambaqui (Aride et al., 2017). Tavares-Dias et al. (2009) described the hematological values of fish produced for commercial purposes in Brazil and indicated that the $\mathrm{Ht}$ values of tambaqui can vary from $26.0 \%$ to $38.0 \%$. Centeno et al. (2007) performed the hematological characterization of tambaqui in cultivation in three stages of life: fingerlings, juveniles, and adults, and obtained the following average Ht values: 29.87, 31.76 and $33.70 \%$, respectively. Despite being different species of fish, specimens of A. gigas pirarucu fed a diet containing glucomannan, derived from yeasts and algae, showed $\mathrm{Ht}$ values similar to those in the present study, when farmed for a period of 45 days (Hoshino et al., 2017).

The $\mathrm{RBC}$ and $\mathrm{Hb}$ values of the tambaqui in the present study were similar to those described by Tavares-Dias et al. (2009). Furthermore, these results were similar to those reported by Chagas and Val (2003) in tambaqui with a diet supplemented with $100 \mathrm{mg}$ of ascorbic acid/kg, vitamin 
present in fruits and vegetables, resulting in $\mathrm{Hb}$ and $\mathrm{RBC}$ values: $8.11 \pm 0.58$ g. $\mathrm{dL}^{-1} \mathrm{e} 1.60 \pm 0.13 \times 10^{6} \mathrm{~mm}^{-3}$, respectively. However, Centeno et al. (2007) observed a tendency of $\mathrm{Hb}$ increasing as the $C$. macropomum specimens grow, thus obtaining higher values in adult individuals. It is noteworthy that values below those described in literature cited for $\mathrm{Ht}, \mathrm{Hb}$ and $\mathrm{RBC}$, can result in a profile of anemia (Chagas and Val, 2003; Chagas et al., 2013). Thus, the results of the present study show that the specimens are in a good health.

The hematological indices did not change due to the supplementation of diets with silage, with only an increase in $\mathrm{MCH}$ values observed with a feeding period of 90 days. Similar values to these were described by Drumond et al. (2010) for the pirarucu A. gigas in semi-intensive fish farm (mean values of MCV and MCHC: $159.8 \pm 21 \mathrm{fL}$ and 27.1 g.dL ${ }^{-1}$, respectively). Diets with the inclusion of silage reduced the $\mathrm{MCHC}$, in comparison with those of the tambaqui from the Control group after 90 days of feeding. According to Tavares-Dias et al. (2009), MCHC can present values between 20.0 and 30.0 g.dL ${ }^{-1}$, however in tambaqui from the $0 \%$ silage group this value was higher than indicated by these authors $\left(33.61 \pm 3.32\right.$ g.dL $\left.\mathrm{dL}^{-1}\right)$, as a result of higher $\mathrm{Hb}$ and lower Ht values for this group. Therefore, the values found in the present study are considered adequate for the health of these specimens.

The blood glucose of tambaqui in the present study was similar to the values described by Chagas et al. (2007), who submitted specimens of tambaqui raised in net tanks to different feeding rates. Such results suggest that the specimens do not suffer from a hyperglycemic condition, or signs of stress, due to the presence of different silage levels in the diets. Silva et al. (2020) reported that tambaqui fed diets with the inclusion of over $16 \%$ whole banana bran exhibited hyperglycemia, with values above $78.0 \mathrm{mg} \cdot \mathrm{dL}^{-1}$. Furthermore, Chagas et al. (2007) identified total plasma protein values considered adequate for tambaqui, that is, above $2.0 \mathrm{~g} . \mathrm{dL}^{-1}$. The triglyceride levels, on the other hand, were higher, as in the study by Silva et al. (2020). This increase in triglycerides may be linked to high amounts of carbohydrates in the diet related by Silva et al. (2020), which was not found in the present study. Ribeiro et al. (2017) did not observe changes in the hematological and biochemical parameters of $A$. gigas fed for 60 days with diets with up to $20 \%$ inclusion of the fish protein hydrolysate and suggested this formulation as an adequate supplement to the diet of these fish.

\section{Conclusion}

The $5 \%, 10 \%$ and $20 \%$ inclusion of silage produced with fish and vegetables residues in the diets of the tambaqui did not cause changes in biometric parameters, even with the use of diets with a lower percentage of $\mathrm{CP}$ in the formulation. The use of fish ration with lower percentage of CP are generally less expensive for producers, enabling the growth of fish and profit for fish farmer. In addition, the hematological and biochemical parameters showed some variation based on the levels of silage inclusion used, but this did not promote harmful to the health of the tambaqui. Therefore, the use of silage as a feed supplement during the tambaqui farming can be recommended as a less costly and more sustainable alternative for producers, promoting a disposal reduction of important residues (fish and vegetable), which are suitable for consumption, and enabling an increase in fish production with the preservation of the environment.

\section{Acknowledgements}

The authors thank the Brazilian Agriculture and Livestock Research Corporation (Embrapa Amapá); CNPq for providing the Master's scholarship to M.N.F. Costa; and the Amapá State Research Support Foundation (FAPEAP) for financial support.

\section{References}

ARAÚJO-LIMA, C. and GOULDING, M., 1998. Os frutos do tambaqui: ecologia, conservação e cultivo na Amazônia. Tefé: Sociedade Civil Mamirauá; Brasília: CNPq, 188 p.

ARIDE, P.H.R., OLIVEIRA, A.M., FERREIRA, M.S., LIEBL, A.R.S., COMASSETTO, L.E., LADISLAU, D.S., BASSUL, L.A., SILVA, B.R., MATTOS, D.C., LAVANDER, H.D., SOUZA, A.B., POLESE, M.F., RIBEIRO, M.W.S., CASTRO, P.D.S. and OLIVEIRA, A.T., 2021. Growth and hematological responses of tambaqui, Colossoma macropomum fed different levels of rice, Oryza spp. Brazilian Journal of Biology = Revista Brasileira de Biologia, vol. 81, no. 4, pp. 962-968. http:// dx.doi.org/10.1590/1519-6984.232560. PMid:33053132.

ARIDE, P.H.R., OLIVEIRA, A.M., BATISTA, R.B., FERREIRA, M.S., PANTOJA-LIMA, J., LADISLAU, D.S., CASTRO, P.D.S. and OLIVEIRA, A.T., 2017. Changes in physiological parameters of tambaqui (Colossoma macropomum) fed with diets supplemented with Amazonian fruit camu camu (Myrciaria dubia). Brazilian Journal of Biology = Revista Brasileira de Biologia, vol. 78, no. 2, pp. 360-367. http://dx.doi.org/10.1590/1519-6984.169442. PMid:28954015.

ARRUDA, L.F., BORGHESI, R., BRUM, A., D'ARCE, M.R. and OETTERER, M., 2006. Nutritional aspects of nile tilapia (Oreochromis niloticus) silage. Food Science and Technology, vol. 26, no. 4, pp. 749-753. http://dx.doi.org/10.1590/S0101-20612006000400006.

ASSOCIATION OF OFFICIAL ANALYTICAL CHEMISTS - AOAC, 1995. Official methods of analysis. 16th ed. Arlington: AOAC, $1141 \mathrm{p}$.

BOAVENTURA, T.P., PEDRAS, P.P.C., SANTOS, F.A.C., FERREIRA, A.L., FAVERO, G.C., PALHETA, G.D.A., MELO, N.F.A.C. and LUZ, R.K., 2021. Cultivation of juvenile Colossoma macropomum in different colored tanks in recirculating aquaculture system (RAS): effects on performance, metabolism, and skin pigmentation. Aquaculture, vol. 532, pp. 736079. http://dx.doi.org/10.1016/j. aquaculture.2020.736079.

BONFÁ, C.S., VILLELA, S.D.J., CASTRO, G.H.F., SANTOS, R.A., EVANGELISTA, A.R. and PIRES NETO, O.S., 2017. Silagem de capim-elefante adicionada de casca de abacaxi. Revista Ceres, vol. 64, no. 2, pp. 176-182. http://dx.doi.org/10.1590/0034737x201764020010.

BOSCOLO, W.R., HAYASHI, C., MEURER, F., FEIDEN, A. and BOMBARDELLI, R.A., 2004. Digestibilidade aparente da energia e proteína das farinhas de resíduo da filetagem da tilápia do Nilo (Oreochromis niloticus) e da corvina (Plagioscion squamosissimus)e farinha integral do camarão canela (Macrobrachium amazonicum) para a tilápia do Nilo. Revista Brasileira de Zootecnia, vol. 33, no. 1, pp. 8-13. http://dx.doi.org/10.1590/S1516-35982004000100002.

CENTENO, L., SILVA-ACUÑA, R., LUGO, R.S., BARRIOS, R., MATUTE, C. and PÉREZ, J.L., 2007. Características hematológicas de la cachama (Colossoma macropomum) entres etapas de crecimiento 
cultivadas enel estado Delta Amacuro, Venezuela. Zootecnia Tropical, vol. 25, no. 4, pp. 237-243.

CHAGAS, E.C. and VAL, A.L., 2003. Efeito da vitamina C no ganho de peso em parâmetro hematológico de tambaqui. Pesquisa Agropecuária Brasileira, vol. 38, no. 3, pp. 397-402. http://dx.doi. org/10.1590/S0100-204X2003000300009.

CHAGAS, E.C., GOMES, L. C., MARTINS JÚNIOR, H. and ROUBACH, R., 2007. Produtividade do tambaqui criado em tanques-rede com diferentes taxas de alimentação. Ciência Rural, vol. 37, no. 4, pp. 1109-1115. http://dx.doi.org/10.1590/S0103-84782007000400031.

CHAGAS, E.C., PILARSKI, A.L.F., SAKABE, R. and MORAES, F.R., 2013. Desempenho produtivo e respostas fisiopatológicas de tambaquis alimentados com ração suplementada com $\beta$-glucano. Pesquisa Agropecuária Brasileira, vol. 48, no. 8, pp. 899-905. http://dx.doi.org/10.1590/S0100-204X2013000800013.

CORRÊA, C.F., OLIVEIRA, T.S., LEONARDO, A.F., REIS-NETO, R.V. and ENKE, D.B.S., 2020. Acid fish silage in the diet of pacu and tambacu reared at cold suboptimal temperature. Pesquisa Agropecuária Brasileira, vol. 55, e01653. http://dx.doi. org/10.1590/s1678-3921.pab2020.v55.01653.

CYRINO, J.E.P., BICUDO, A.J.A., SADO, R.Y., BORGHESI, R. and DAIRIKI, J.K., 2010. A piscicultura e o ambiente: o uso de alimentos ambientalmente corretos em piscicultura. Revista Brasileira de Zootecnia, vol. 39, suppl. spe, pp. 68-87. http://dx.doi. org/10.1590/S1516-35982010001300009.

DRUMOND, G.V.F., CAIXEIRO, A.P.A., TAVARES-DIAS, M., MARCON, J.L. and AFFONSO, E.G., 2010. Características bioquímicas e hematológicas do pirarucu Arapaima gigas Schinz, 1822 (Arapaimidae) de cultivo semi-intensivo na Amazônia. Acta Amazonica, vol. 40, no. 3, pp. 591-595. http://dx.doi.org/10.1590/ S0044-59672010000300020.

FAZIO, F., 2019. Fish hematology analysis as an important tool of aquaculture: a review. Aquaculture, vol. 500, pp. 237-242. http:// dx.doi.org/10.1016/j.aquaculture.2018.10.030.

GAO, R., YU, Q., SHEN, Y., CHU, Q., CHEN, G., FEN, S., YANG, M., YUAN, L., MCCLEMENTS, D.J. and SUN, Q., 2021. Production, bioactive properties, and potential applications of fish protein hydrolysates: developments and challenges. Trends in Food Science \& Technology, vol. 110, pp. 687-699. http://dx.doi.org/10.1016/j.tifs.2021.02.031.

GOULDING, M. and CARVALHO, M., 1982. Life history and management of the tambaqui (Colossoma macropomum, Characidae): an important Amazonian food fish. Revista Brasileira de Zoologia, vol. 1, no. 2, pp. 107-133. http://dx.doi. org/10.1590/S0101-81751982000200001.

GUIMARÃES, C.C., MACIEL, I.V., SILVA, A.F., SOUZA, A.F.L., CARPIO, K.C.R. and SILVA, A.J.I., 2021. Biotechnological aspects of biological silage of Tambaqui residues. Revista em Agronegócio e Meio Ambiente, vol. 14, no. 1, e006861. http://dx.doi. org/10.17765/2176-9168.2021v14n1e006861.

HISANO, H., MARUYAMA, M.R., ISHIKAWA, M.M., MELHORANÇA, A.L. and OTSUBO, A.A., 2008. Potencial da utilização da mandioca na alimentação de peixes. Dourados: Embrapa Agropecuária Oeste, 29 p. (Documentos, no. 94).

HOSHINO, M.D.F.G., MARINHO, R., PEREIRA, D.F., YOSHIOKA, E.T.O., TAVARES-DIAS, M., OZORIO, R.O.A., RODRIGUEZ, A.F.R., RIBEIRO, R.A. and FARIA, F.S.E.D.V., 2017. Hematological and biochemical responses of pirarucu (Arapaima gigas, Arapaimidae) fed with diets containing a glucomannan product derived from yeast and algae. Acta Amazonica, vol. 47, no. 2, pp. 87-94. http://dx.doi. org/10.1590/1809-4392201700781.

LIMA, M.R. and LUDKE, M., 2011. Farelo de resíduo de manga para tilápia do Nilo. Acta Scientiarum. Animal Sciences, vol. 33, no. 1 pp.65-71. http://dx.doi.org/10.4025/actascianimsci.v33i1.10247.
MEURER, F., HAYASHI, C., SOARES, C.M. and BOSCOLO, W.R., 2008. Utilização de levedura spray dried na alimentação de alevinos de tilápia do Nilo (Oreochromis niloticus L.). Acta Scientiarum. Biological Sciences, vol. 22, no. 2, pp. 479-484. http://dx.doi. org/10.4025/actascibiolsci.v22i0.2995.

OLIVEIRA, A.L.T., SALES, R. O., FREITAS, J.B.S. and LOPES, J.E.L., 2013. Alternativa sustentável para descarte de resíduos de pescado em Fortaleza. Revista Brasileira de Higiene e Sanidade Animal, vol. 7, no. 1, pp. 1-8. http://dx.doi.org/10.5935/1981-2965.20120003.

PAULA, K.S.A. and FARIA JÚNIOR, O.L., 2019. Utilização dos restos culturais e resíduos da industrialização de abacaxi na alimentação de ruminantes: revisão. Pubvet, vol. 13, no. 2, pp. 1-7. http://dx.doi.org/10.31533/pubvet.v13n2a271.1-7.

RANZANI-PAIVA, M.J.T., PÁDUA, S.B., TAVARES-DIAS, M. and EGAMI, M.I., 2013. Métodos para análise hematológica em peixes. Maringá: Eduem, 140 p. http://dx.doi.org/10.7476/9788576286530.

RIBEIRO, M.S., FONSECA, F.A.L., QUEIROZ, M.N., AFFONSO, E.G., CONCEIÇÃO, L.E.C. and GONÇALVES, L.U., 2017. Fish protein hydrolysate as an ingredient in diets for Arapaima gigas juveniles. Boletim do Instituto de Pesca, vol. 44, no. especial, pp. 85-92. http://dx.doi.org/10.20950/1678-2305.2017.85.92.

ROTTA, M.A., 2003. Aspectos gerais da fisiologia e estrutura do sistema digestivo dos peixes relacionados à piscicultura. Corumbá: Embrapa Pantanal, 48 p. (Documentos, no. 53).

ROSSETTO, J.F. and SIGNOR, A., 2021. Inovações tecnológicas empregadas em coprodutos gerados pelo processamento do pescado. Pubvet, vol. 15, no. 4, pp. 1-11. http://dx.doi. org/10.31533/pubvet.v15n04a796.1-11.

RUFFINO, M.L. and ROUBACH, R., 2009. A pesca e aquicultura na Amazônia brasileira. In: H.B. ZAMUDIO, C.H. SIERRA, M.A. TARANCÓN and M.O. OLALDE, eds. Amazonía y Agua: desarrollo sostenible en el siglo XXI. Madrid: UNESCO, pp. 249-257.

SILVA, A.F., COPATTI, C.E., OLIVEIRA, E.P., DE., BONFÁ, H.C., MELO, F.V.S.T. and CAMARGO, A.C., 2020. Effects of whole banana meal inclusion as replacement for corn meal on digestibility, growth performance, haematological and biochemical variables in practical diets for tambaqui juveniles (Colossoma macropomum). Aquaculture Reports, vol. 17, pp. 100307-100315. http://dx.doi. org/10.1016/j.aqrep.2020.100307.

TAVARES-DIAS, M., LSHIKAWA, M.M., MARTINS, M.L., SATAKE, F., HISANO, H., DE PÁDUA, S.B., JERÔNIMO, G.T. and SÁ, A.R.S., 2009. Hematologia: ferramenta para o monitoramento do estado de saúde de peixes em cultivo. In: A. SARAN NETO, W.S. MARIANO and S.F.P. SÓRIA, eds. Tópicos especiais em saúde e criação animal. São Carlos: Pedro \& João Editores.

VENDRUSCOLO, F., RIBEIRO, C.S., ESPÓSITO, E. and NINOW, J.L., 2009. Tratamento biológico do bagaço de maçã e adição em dietas para alevinos. Revista Brasileira de Engenharia Agrícola e Ambiental, vol. 13, no. 4, pp. 487-493. http://dx.doi.org/10.1590/ S1415-43662009000400018.

YOSHIOKA, E.T.O., DAMASCENO, L.F. and MARINHO, R. G.B. and ROCHA, J.D.M., 2020. Elaboração de silagem biológica com coprodutos de peixes. Macapá: Embrapa Amapá, 11 p. Comunicado Técnico, no. 160).

YUANGSOI, B., KLAHAN, R., CHAROENWATTANASAK, S. and LIN, S.-M., 2018. Effects of supplementation of pineapple waste extract in diet of Nile tilapia (Oreochromis niloticus) on growth, feed utilization, and nitrogen excretion. Journal of Applied Aquaculture, vol. 30, no. 3, pp. 227-237. http://dx.doi.org/10.1 080/10454438.2018.1439794.

ZAR, J.H., 2010. Biostatistical analysis. 5 th ed. New Jersey: Prentice Hall, 944 p. 